\title{
ANALYSIS OF THE FIBER DISTRIBUTION, SIZE, AND VOLUME RATIO OF UNIDIRECTIONAL COMPOSITE PLATES WITH DIFFERENT THICKNESSES
}

\author{
ANALIZA RAZPOREDITVE VLAKEN, VELIKOSTI IN \\ VOLUMSKEGA DELEŽA V ENOSMERNIH, RAZLIČNO DEBELIH \\ KOMPOZITNIH PLOŠČAH
}

\author{
Robert Zemčík ${ }^{1}$, Hana Srbová2 ${ }^{2}$ Kamil Ekštein ${ }^{3}$, Ivan Pirner $^{4}$, Rostislav Medlín ${ }^{5}$ \\ ${ }^{1}$ University of West Bohemia in Pilsen, NTIS - New Technologies for the Information Society, Univerzitní 22, 30100 Pilsen, Czech Republic \\ 2University of West Bohemia in Pilsen, Department of Mechanics, Univerzitní 22, 30100 Pilsen, Czech Republic \\ ${ }^{3}$ University of West Bohemia in Pilsen, Department of Computer Science and Engineering, Univerzitní 22, 30100 Pilsen, Czech Republic \\ ${ }^{4}$ University of West Bohemia in Pilsen, Department of Cybernetics, Univerzitní 22, 30100 Pilsen, Czech Republic \\ ${ }^{5}$ University of West Bohemia in Pilsen, New Technologies - Research Centre in the West Bohemian Region, Univerzitní 22, 30100 Pilsen, \\ Czech Republic \\ zemcik@kme.zcu.cz
}

Prejem rokopisa - received: 2015-07-02; sprejem za objavo - accepted for publication: 2015-12-18

This work focuses on an assessment of the real fiber and matrix volume ratios of unidirectional fiber composites that can be used for the design of corresponding numerical models on the micro-scale. Samples with polished cross-sections were prepared from three composite plates and they were previously analyzed using scanning electron microscopy (SEM). All the plates were manufactured from the same prepreg material using autoclave technology. Each plate consisted of a different number of plies. Images of the various parts of the composite cross-sections obtained with SEM are analyzed using several image-processing techniques programmed in Matlab, its Image Processing Toolbox, and C code. The results of this analysis are the center positions and radii of all fibers within the image. The fiber and matrix volume ratios are determined subsequently and mutually compared for different locations across the plates' thicknesses.

Keywords: composite, unidirectional, micromechanics, constituents, image, detection, microscopy, cross-section

Delo je osredotočeno na oceno realnih vlaken in volumenskega deleža v osnovi, v enosmernih kompozitih iz vlaken, ki jih je mogoče uporabiti za postavitev ustreznih numeričnih modelov na mikropodročju. Pripravljeni vzorci, s poliranim presekom, iz treh kompozitnih plošč, so bili pregledani s pomočjo vrstičnega elektronskega mikroskopa (SEM). Vse plošče so bile izdelane iz enakega, $v$ avtoklavih izdelanega, predimpregniranega materiala. Vsaka plošča je bila sestavljena iz različnega števila plasti. Posnetki različnih delov preseka kompozita, dobljeni s SEM, so bili analizirani z več tehnikami za obdelavo slik, programiranimi v Matlab, Image Processing Toolbox in C-kodo. Rezultati teh analiz so pozicije sredine in radiji vseh vlaken na posnetku. Pozneje so bili določeni, in medsebojno primerjani, volumenski deleži vlaken na različnih lokacijah preko debeline plošče.

Ključne besede: kompozit, enosmeren, mikromehanika, gradniki, posnetek, odkrivanje, mikroskopija, prečni presek

\section{INTRODUCTION}

All methods of fabricating unidirectional fiber-reinforced composites result in a non-uniform distribution of fibers in the matrix. The fiber distribution affects the mechanical properties of the composite. In ${ }^{1}$ the local stress fields and damage initiation in dependence on the fiber distribution are investigated. Although the fiber volume ratio (usually designated as $v_{\mathrm{f}}$ ) determines the geometry of composite micromodels and subsequently the identified homogenized material properties ${ }^{2}$, it is a problem to determine it precisely. For example, a fiber composite structure manufactured by transfer molding method typically ranges between approximately $v_{\mathrm{f}}=0.5$ and $v_{\mathrm{f}}=0.6 .^{3}$ The actual value can be different in various parts of the structure and it can significantly influence the local properties, such as the stiffness, strength, or durability.

\section{EXPERIMENTAL PART}

Three specimens were cut out from three different carbon/epoxy plates (designated as A, B, and C) using a water jet. Each plate was made of a different number (1, 2 , and 4) of similar autoclaved prepreg layers. The specimens were fixed in epoxy resin and their cross-sections were polished on a low-speed polishing machine.

Gray-scale images of various parts of the cross-sections were obtained using scanning electron microscopy (SEM). The images were obtained using a magnification factor of 4000 with $15.9 \mathrm{px} / \mu \mathrm{m}$ (pixels per micrometer), as shown in Figure 1. They were taken at the top, middle and bottom regions of the plate's thickness. An example of the image in Figure 2 with a full thickness view (obtained using magnification factor of 150) shows the layers and approximate position of the three investigated areas. 
R. ZEMČÍK et al.: ANALYSIS OF THE FIBER DISTRIBUTION, SIZE, AND VOLUME RATIO OF UNIDIRECTIONAL ...

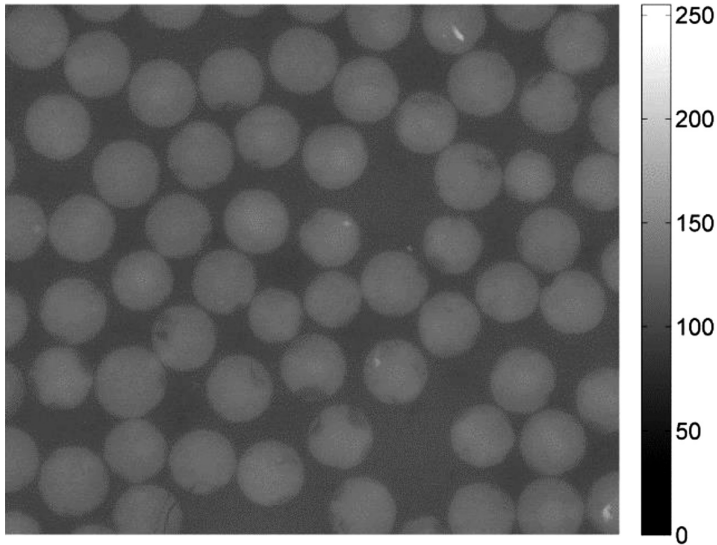

Figure 1: Original image of bottom area of plate C, intensity values range from 82 to 201

Slika1: Originalni posnetek spodnjega dela plošče C, vrednosti intenzitete so med 82 in 201

In general, the quality of the obtained SEM images is quite low and the contrast varies between the different areas and samples. Therefore, the following automated image analysis includes several quality-improving steps.

\section{IMAGE PROCESSING}

The design stage of the image-processing algorithm was preceded by a thorough analysis of the obtained gray-scale microscopic images of the material cuts. Each image is a matrix $f(x, y)$ with pixel intensity values ranging from 0 to 255 and $x$ and $y$ being the pixel coordinates ( $x=1 . . M, y=1 . . N$, where $M \times N$ defines the image size). All these images demonstrated a substantial, strong

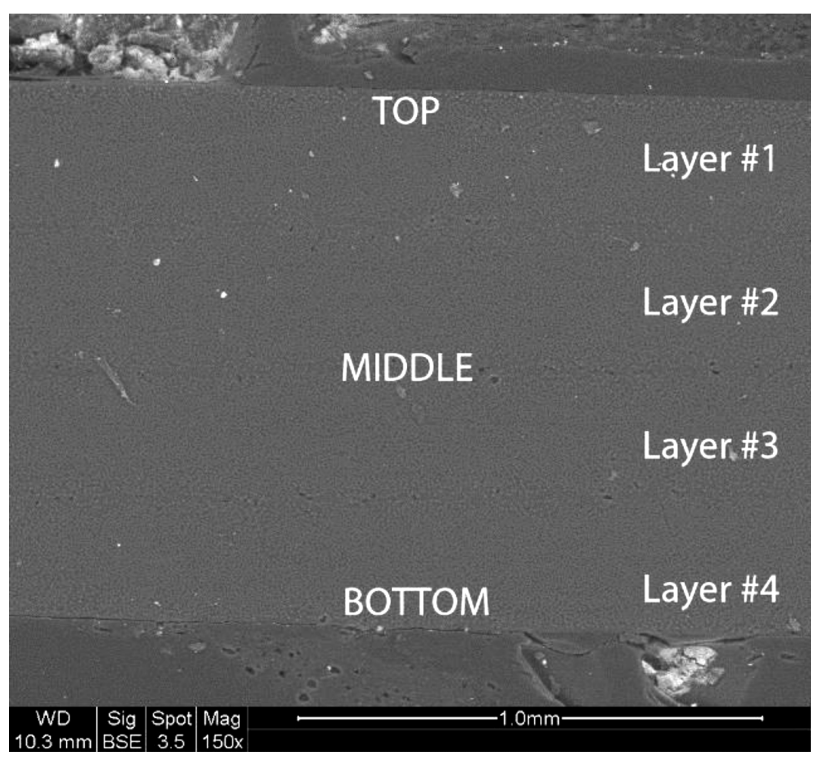

Figure 2: Cross-section of unidirectional composite plate $(C)$ made of 4 prepregs obtained using SEM, approximate locations of investigated areas (top, middle, and bottom) are marked

Slika 2: SEM-posnetek preseka enosmerne kompozitne plošče (C), izdelane iz 4 predimpregniranih plasti, označeni so približni položaji preiskovanega področja (vrh, sredina, dno) common trait, which is a rather small contrast gradient over the whole image. Thus, the standard computer vision methods for both edge detection and binarization provide poor results or fail completely, which makes the object detection impossible.

The analysis of the image collection proved that the tonal distribution of the gray-scale images (represented by a histogram of pixel values) is of a bimodal nature. It clearly indicates that the image can be successfully segmented so that two global regions are identified: a background and the desired set of foreground objects, in this case the fibers of the composite material.

However, due to the small contrast gradient the bimodal histogram - or rather its region of the highest interest where the binarization threshold is located - is very narrow and even a minor inaccuracy in the position of the threshold can spoil the binarization. Unfortunately, the traditional reliable techniques for threshold detection, like, e.g., the Otsu method, set the binarization threshold in this case completely incorrectly. The Otsu method is a robust efficient technique for binarization-threshold estimation used in most of the computer-vision toolboxes. It is used, for instance, by MATLAB's im2bw function for image binarization. ${ }^{4}$

Thus, a new robust method for threshold estimation on images with bimodal histograms was needed.

\section{THRESHOLD ESTIMATION}

Before computing the threshold estimate the original image $f(x, y)$ is filtered by a median filter over a $3 \times 3$ neighborhood. Then, a histogram $h(i)$ of pixel intensities $i=0 \ldots 255$ is computed. The obtained histogram must be weighted before further processing as it has usually rather extreme values at both ends, i.e., both very low and very high intensities are contained heavily in the image (mostly due to the black-and-white state information added by the microscope software). The weighting is performed by a Hann window. The weighted histogram is then smoothed by Gaussian smoothing, a convolution filtering with a Gaussian kernel. The neighborhood used for the discrete convolution is an odd ceiling of $2.5 \%$ of the whole histogram length, i.e., for the 256-bin histogram seven neighboring values are used. The value of the variance is set to 1 .

The weighted smoothed histogram is numerically differentiated in order to get an estimate of the first derivative $\mathrm{d} h / \mathrm{d} i$ with respect to the intensity. The derivative is smoothed by the same Gaussian filter as mentioned above. In the next step, the histogram derivative is gated.

A list of threshold position candidates is assembled by searching for zero values of the histogram. Since the histogram is discrete a zero-crossing detection algorithm is applied.

Depending on the character of the input image, the candidate list should have 2 or 3 items (although under real conditions, it might have more than three and the 


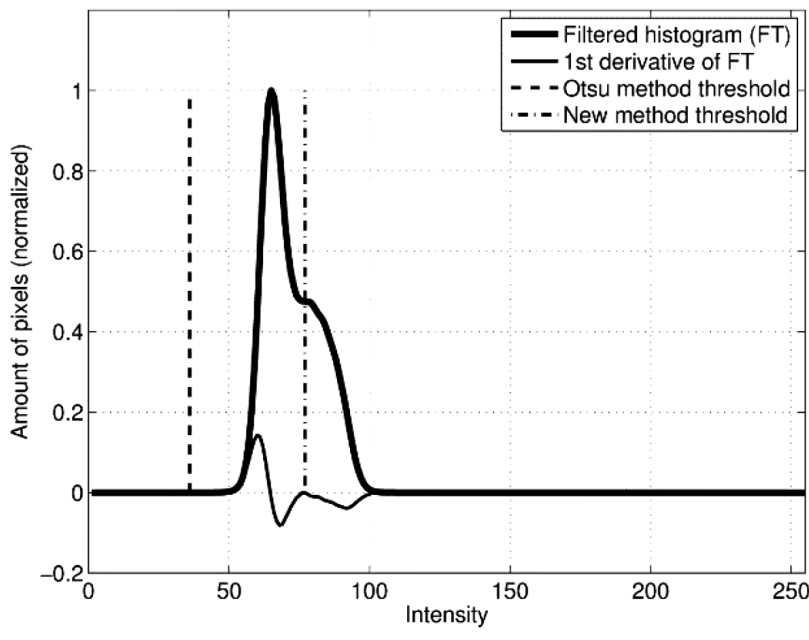

Figure 3: Threshold estimation from histogram

Slika 3: Prag, določen iz histograma

algorithm is robust to this case). One of the candidate items is always equal to the position of the maximum value in the histogram. Then, the threshold position $t$ is set to the next candidate in the direction towards the side where there is more remaining candidates - in the case with three or more candidates in the list. If there are only two candidates, the threshold position is set to the candidate not equal to the maximum position (such situation is depicted in Figure 3).

\section{FIBER CENTER DETECTION}

The original gray-scale image $f$ is binarized to $f_{\text {bin }}$ (Figure 4) using the threshold value $t$ obtained above:

$$
f_{\text {bin }}(x, y)=\left\{\begin{array}{l}
0, f(x, y)<t \\
1, f(x, y) \geq t
\end{array}\right.
$$

and then processed by dilation. ${ }^{5}$ The dilated image (Figure 5) is obtained as:

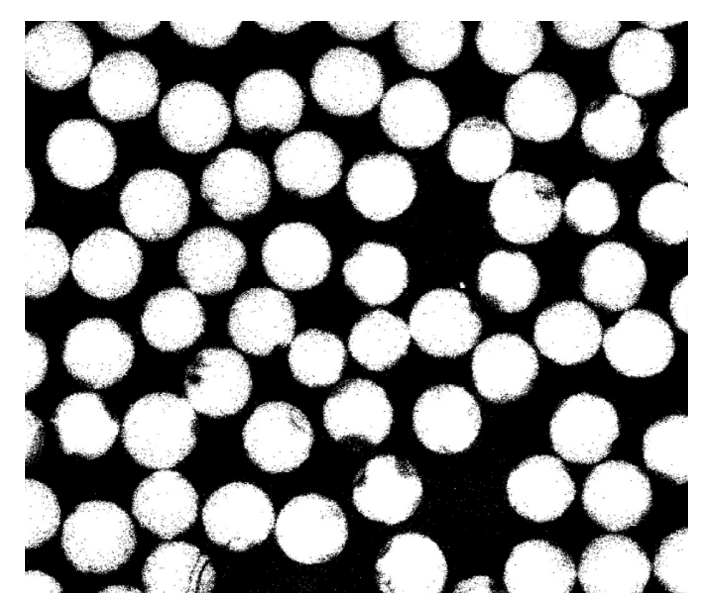

Figure 4: Binary image of bottom area of plate $C$, threshold intensity was determined to be $i=118$

Slika 4: Binarna slika spodnjega dela plošče $C$, intenziteta praga je bila določena kot $i=118$

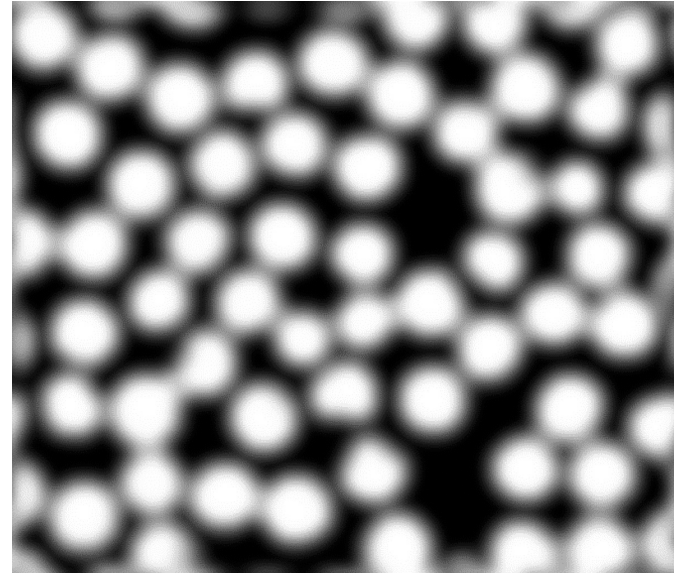

Figure 5: Dilated image of bottom area of plate C Slika 5: Razširjena slika spodnjega dela plošče C

$$
\begin{aligned}
& \bar{f}(x, y)=\left(f_{\text {bin }} \oplus g\right)(x, y)= \\
& \max \left\{f\left(x-x^{\prime}, y-y^{\prime}\right)+g\left(x^{\prime} y^{\prime}\right) \mid\left(x^{\prime} y^{\prime}\right) \in D_{\text {B }}\right\}
\end{aligned}
$$

where $g$ is binary structuring matrix $(5 \times 5)$ of ones, with rectangular domain $D_{\mathrm{B}} .^{4}$

The preprocessed image, a circle binary mask of the minimum fiber cross-section size and a discrete spatial matrix $^{6}$ are then transformed with two-dimensional discrete Fourier transform:

$$
F(u, v)=\sum_{n=0}^{N-1} \sum_{m=0}^{M-1} f(x, y) \cdot e^{\left(-2 \pi i \cdot\left(\frac{n x}{N}+\frac{m y}{M}\right)\right)}
$$

where $F$ is the image matrix in spatial frequencies $u$ and $v$. Matrix $G$ in spatial frequencies is obtained by discrete convolution:

$$
G(u, v)=F(u, v) *(H(u, v) \cdot Q(u, v))
$$

where $H$ is a binary mask and $Q$ is the matrix transformed by the Fourier transform (3). Its local maxima are considered as the fiber center positions $\left(x_{j}, y_{j}\right) .^{4,6}$

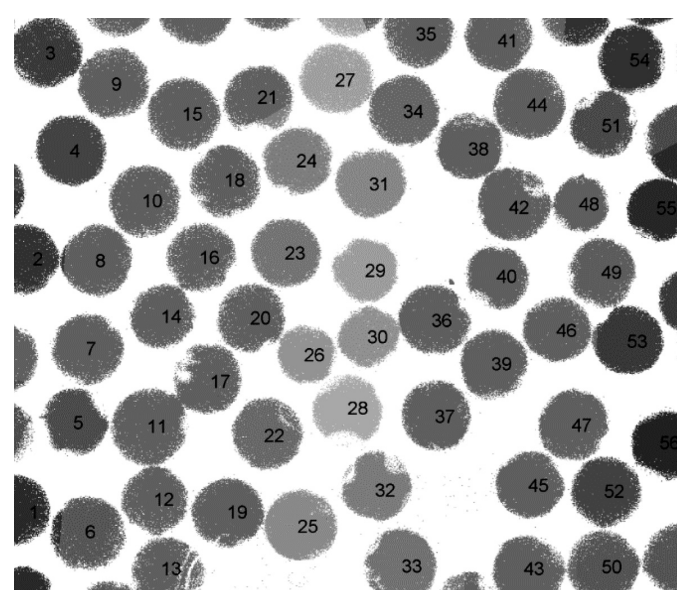

Figure 6: Clustered image of bottom area of plate $\mathrm{C}$, in total, 56 clusters were detected

Slika 6: Slika gruč v spodnjem delu plošče C, skupaj je bilo odkritih 56 gruč 


\section{MATERIALI IN TEHNOLOGIJE/MATERIALS AND TECHNOLOGY (1967-2017) - 50 LET/50 YEARS}

R. ZEMČÍK et al.: ANALYSIS OF THE FIBER DISTRIBUTION, SIZE, AND VOLUME RATIO OF UNIDIRECTIONAL ...

\section{RADIUS AND AREA DETECTION}

Further, a cluster analysis was applied to the binary image $f_{\text {bin. }}$. The cluster analysis is an iterative process where a set of similar objects (pixels with similar intensity) is assigned to a group (cluster). The center positions. In this case a hierarchical clustering method was used. Each cluster belongs to one of the center positions $\left(x_{j}, y_{j}\right)$. The fiber area $S_{j}$ is calculated as the number of pixels assigned to each cluster $j$ (Figure 6) and the corresponding fiber radius $r_{j}$ is then approximated by Equation (5):

$$
r_{j}=\sqrt{\frac{S_{j}}{\pi}}
$$

The fiber volume ratio $v_{f}$ is then calculated as the ratio of pixels corresponding to all the fibers and the total number of pixels (in the selected rectangular area).

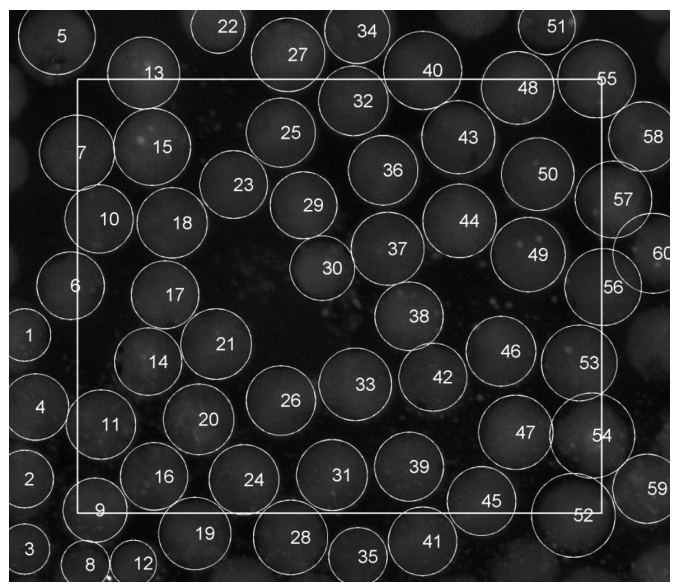

Figure 7: Analyzed top area of plate A, gray-scale from SEM with maximized contrast; circles denote detected fibers (position and size) Slika 7: Analiziran vrhnji del plošče A, SEM-posnetek s povečanim kontrastom; krogi označujejo odkrita vlakna (pozicijo in velikost)

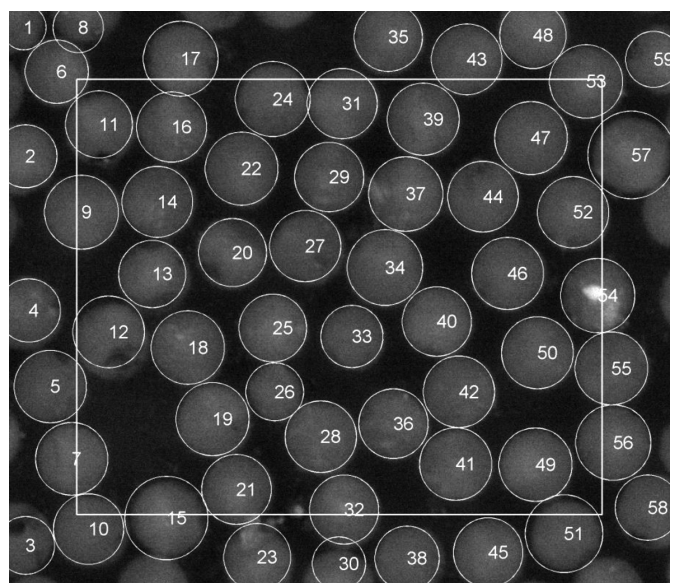

Figure 8: Analyzed middle area of plate A, gray-scale from SEM with maximized contrast, circles denote detected fibers (position and size) Slika 8: Analizirano srednje področje plošče A, SEM-posnetek s povečanim kontrastom, krogi označujejo odkrita vlakna (pozicijo in velikost)

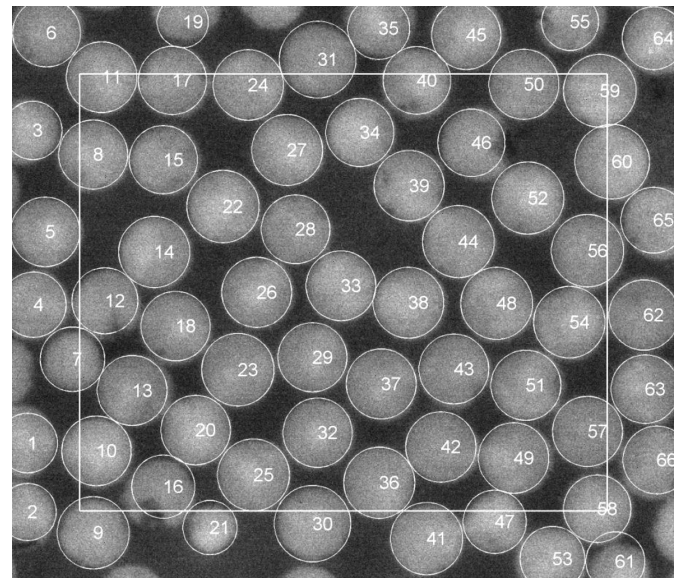

Figure 9: Analyzed bottom area of plate A, gray-scale from SEM with maximized contrast, circles denote detected fibers (position and size) Slika 9: Analiziran spodnji del plošče A, SEM-posnetek s povečanim kontrastom, krogi označujejo odkrita vlakna (pozicijo in velikost)

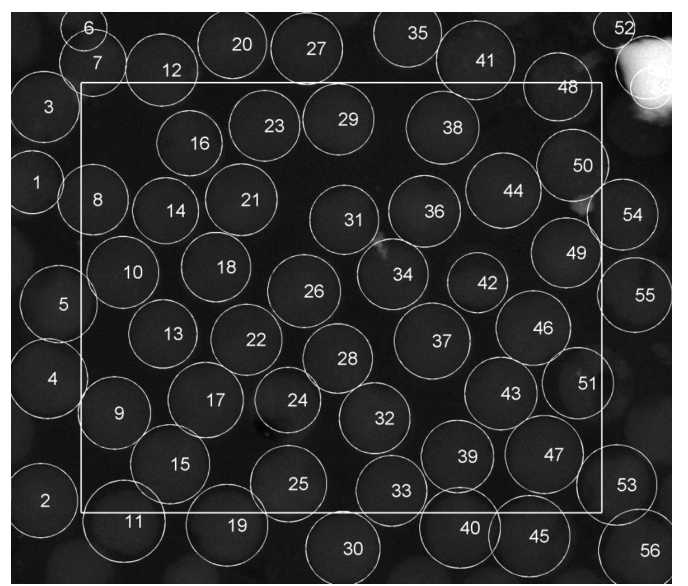

Figure 10: Analyzed top area of plate B, gray-scale from SEM with maximized contrast, circles denote detected fibers (position and size) Slika 10: Analiziran zgornji del plošče B, SEM posnetek s povečanim kontrastom, krogi označujejo odkrita vlakna (pozicijo in velikost)

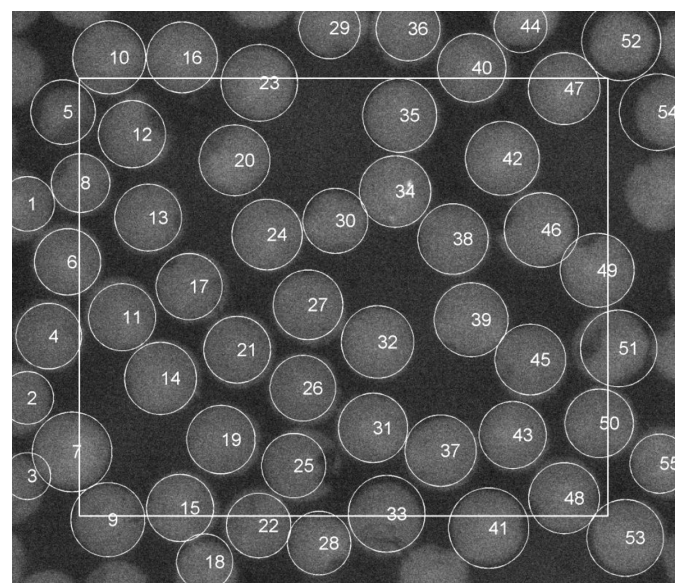

Figure 11: Analyzed middle area of plate B, gray-scale from SEM with maximized contrast, circles denote detected fibers (position and size)

Slika 11: Analiziran srednji del plošče B, SEM-posnetek s povečanim kontrastom, krogi označujejo odkrita vlakna (pozicijo in velikost) 


\section{R. ZEMČÍK et al.: ANALYSIS OF THE FIBER DISTRIBUTION, SIZE, AND VOLUME RATIO OF UNIDIRECTIONAL ...}

\section{RESULTS}

All the images were analyzed using the above-described process. The positions and sizes of the detected fibers (cyan circles with cluster IDs) are shown in Figures 7 to 15 . The gray-scale images are shown with maximized contrast. The yellow rectangle denotes an area for which the fiber volume ratio and the average fiber radius were calculated. The calculated values (together with standard deviation "SD") are summarized in Table 1. It was found that the volume ratio is slightly larger in the top and bottom areas in all the plates. The average fiber radius in all the plates was found to be 54.5276 px, which corresponds to $3.4294 \mu \mathrm{m}$.

Table 1: Properties obtained from images

Tabela 1: Lastnosti, dobljene iz posnetkov

\begin{tabular}{|l|c|c|c|}
\hline \multirow{1}{*}{$\begin{array}{c}\text { Image } \\
\text { area }\end{array}$} & $\begin{array}{c}\text { Fiber volume } \\
\text { ratio } \\
v_{\mathrm{f}}\end{array}$ & $\begin{array}{c}\text { Averaged fiber } \\
\text { radius } \\
(r)\end{array}$ & $\begin{array}{c}\text { Fiber radius } \\
\mathrm{SD} \\
\mathrm{sd}(r)\end{array}$ \\
\cline { 2 - 4 } & $(-)$ & $(\mathrm{px})$ & $(\mathrm{px})$ \\
\hline A-top & 0.62378 & 55.4685 & 3.3918 \\
\hline A-middle & 0.61156 & 55.2918 & 3.5781 \\
\hline A-bottom & 0.65256 & 53.8739 & 2.6742 \\
\hline B-top & 0.63991 & 56.2806 & 3.6586 \\
\hline B-middle & 0.53645 & 54.2127 & 3.6388 \\
\hline B-bottom & 0.60706 & 58.3071 & 4.7778 \\
\hline C-top & 0.58752 & 53.1380 & 4.1013 \\
\hline C-middle & 0.43809 & 52.6896 & 4.1948 \\
\hline C-bottom & 0.54454 & 51.4864 & 3.6767 \\
\hline
\end{tabular}

\section{CONCLUSIONS}

A new approach was proposed for an accurate estimation of the threshold value that is necessary for the creation of a proper binary map and subsequent clustering of the objects in images. The method was used for the detection of fibers in images of cross-sections of unidirectional composite plates obtained by SEM. The

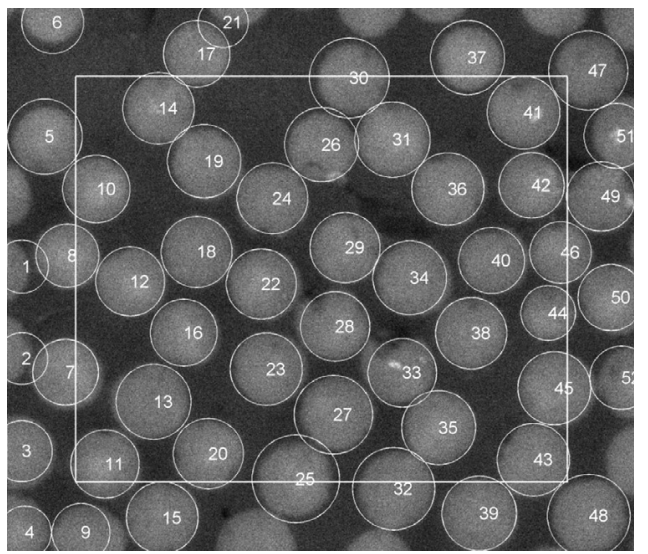

Figure 12: Analyzed bottom area of plate B, gray-scale from SEM with maximized contrast, circles denote detected fibers (position and size)

Slika 12: Analiziran spodnji del plošče , SEM-posnetek s povečanim kontrastom, krogi označujejo odkrita vlakna (pozicijo in velikost)

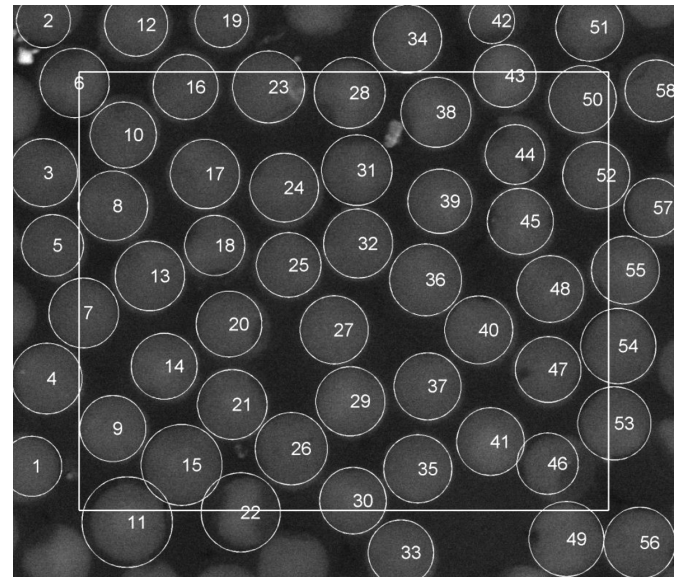

Figure 13: Analyzed top area of plate C, gray-scale from SEM with maximized contrast, circles denote detected fibers (position and size) Slika 13: Analiziran zgornji del plošče C, SEM-posnetek s povečanim kontrastom, krogi označujejo odkrita vlakna (pozicijo in velikost)

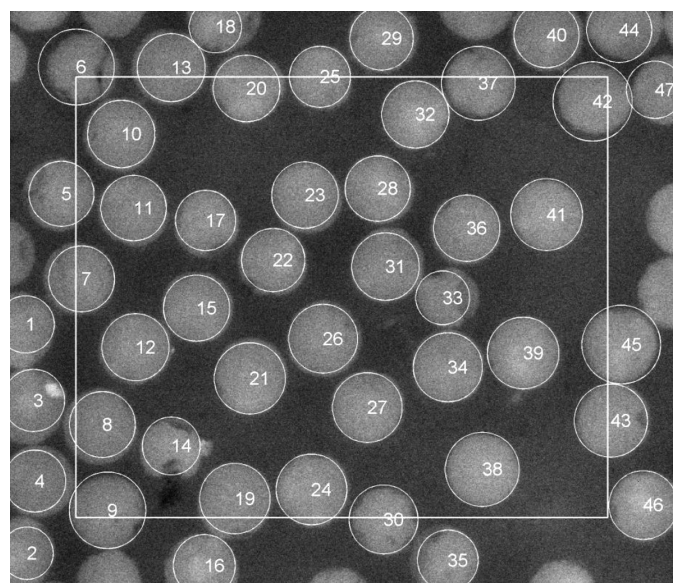

Figure 14: Analyzed middle area of plate C, gray-scale from SEM with maximized contrast, circles denote detected fibers (position and size)

Slika 14: Analiziran srednji del plošče C, SEM-posnetek s povečanim kontrastom, krogi označujejo odkrita vlakna (pozicijo in velikost)

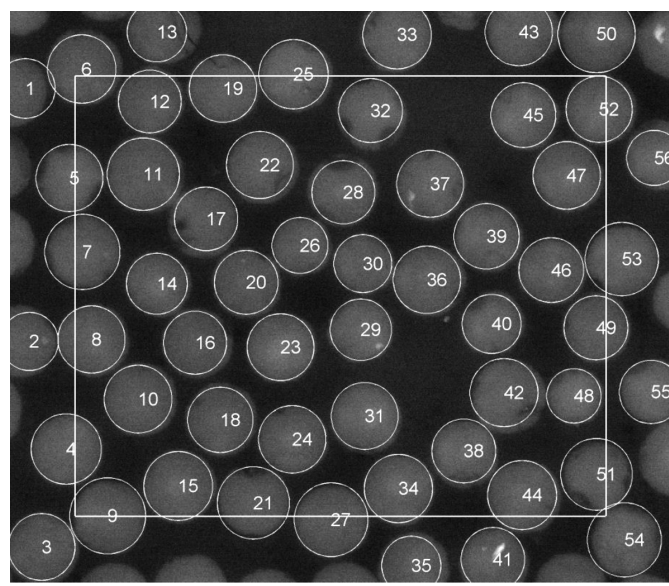

Figure 15: Analyzed bottom area of plate C, gray-scale from SEM with maximized contrast, circles denote detected fibers (position and size)

Slika 15: Analiziran spodnji del plošče C, SEM-posnetek s povečanim kontrastom, krogi označujejo odkrita vlakna (pozicijo in velikost) 


\section{MATERIALI IN TEHNOLOGIJE/MATERIALS AND TECHNOLOGY (1967-2017) - 50 LET/50 YEARS}

R. ZEMČÍK et al.: ANALYSIS OF THE FIBER DISTRIBUTION, SIZE, AND VOLUME RATIO OF UNIDIRECTIONAL ...

method provided acceptable results, even in the case of relatively low-quality (low-contrast) images. The analysis also showed that the fiber volume ratio tends to have larger values at the surfaces of the composite, rather than in the center of the plates. Such data are important for reliable micromechanical models. ${ }^{7}$

\section{Acknowledgement}

The work was supported by the European Regional Development Fund (ERDF), through project "NTIS New Technologies for Information Society", European Centre of Excellence, CZ.1.05/1.1.00/02.0090, by project LO1506 PUNTIS, and by the student research project of Ministry of Education of Czech Republic SGS-2013-036.

\section{REFERENCES}

${ }^{1}$ B. F. Sorenson, R. Tarleja, Effects of nonuniformity of fiber distribution on thermally-induced residual stresses and cracking in ceramic matrix composites, Mechanics of Materials, 16 (1993), 351-363

${ }^{2}$ V. Laš, Mechanics of Composite Materials, University of West Bohemia, Pilsen 2008

${ }^{3}$ R. T. Reavely, W. Kim, Method of fabricating fiber reinforced composite articles by resin transfer molding, United States Patent, Patent no. 4988469, Jan. 29, 1991

${ }^{4}$ User's Guide (R2013a), Mathworks, 2013, http://www.mathworks. com/help/

${ }^{5}$ M. Železný, Digital image processing, Lectures, Department of Cybernetics, Faculty of Applied Sciences, University of West Bohemia, http://www.kky.zcu.cz/uploads/courses/zdo/ZDO_aktual_ 130215.pdf

${ }^{6}$ H. Srbová, I. Pirner, R. Zemčík, R. Medlín, Analysis of fiber distribution and volume ratio of unidirectional composite for micromodels, Transactions of the VŠB - Technical University of Ostrava, Mechanical Series, LIX (2013) 3

${ }^{7}$ T. Kroupa, H. Srbová, R. Zemčík, Identification of the initial failure and damage of substituens of a unidirectional fiber-reinforced composite using am micromodel, Mater. Tehnol., 48 (2014) 4, $549-553$ 